\title{
Knowledge Management in MCDA Domain
}

\author{
Jarosław Wątróbski ${ }^{1}$ \\ Jarosław Jankowski ${ }^{1,2}$ \\ ${ }^{1}$ West Pomeranian University of Technology in Szczecin, Żołnierska 49, 71-210 Szczecin, Poland \\ Email: \{jjankowski, jwatrobski\}@wi.zut.edu.pl \\ ${ }^{2}$ Department of Computational Intelligence, Wrocław University of Technology, Wybrzeże Wyspiańskiego 27 , \\ 50-370 Wrocław, Poland
}

\begin{abstract}
Multi-criteria decision analysis (MCDA) methods have become increasingly popular in decision-making. Numerous methods in this field were developed to solve realworld decision problems including various engineering and scientific areas. Unfortunately, the proper use of each method is difficult due to the dispersion of the domain knowledge and lack of knowledge databases in this area.

The paper presents research focused on knowledge management aspects in MCDA domain. In order to achieve a high level of practicality on different levels of decision making, the ontology as a form of conceptualization is implemented.
\end{abstract}

\section{INTRODUCTION}

$\mathrm{T}$ ogether with the development of operational research, as an alternative approach evolution of MCDA methods has been observed. This applies both in theoretical studies that result in the continuous development of existing methodologies and techniques, and in the emergence of new methods as well as the application layer covering new areas of application methods in business practice.

In each case of individual specification of environmental decision-making situations, the selection of a multi-criteria method should be carried out with great care [1], and the recommendations of selection techniques for modeling and aggregation of preference should be carried out with the following considerations:

- taking into account a detailed specification of the discussed problems and pending issues, including their complex and multi-level character,

- an intuitive dialogue with the decision-maker and the user at the stage of formulating and implementing the assessment process with the subjective linguistic approach implemented,

- possible use of imprecise preference information by the evaluators, including variability of the assessment,

- the possibility of missing a situation assessment and incomparability of decision variants for multiple forms of preferential information with the deterministic, not deterministic, ordinal or fuzzy character.
The natural consequence of various areas of application of multi-criteria methods is the need for the development of dedicated approaches adjusted to the specifics of the problem. This is confirmed by a detailed analysis of the literature, where research in various scientific disciplines is effectively carried out using a number of multi-criteria methods [13] [11]. Combined with a variety of specific decision problems discussed by the authors of studies in this field, the natural direction of research can be an attempt to systematize the knowledge in this area. An additional prerequisite for undertaking research in this area is a large heterogeneity of domain knowledge including available scientific publications and the existing decision support systems.

In the literature, attempts to develop models of knowledge representation of MCDA problems and methods areas can be observed. For example, the article [6] presents an ontology designed to describe the structure of decisionmaking problems. It is a component of the support for the group decision-making processes. On the other hand, in [8] an ontological representation of the multi-criteria method of AHP and a set of inference rules were developed. In this way, clearly defined and formalized concepts related to the method of AHP and knowledge reusing allowed implementation in the form of ontologies. Earlier studies of systematized knowledge about various aspects of decisionmaking are presented [9][10]. One of the approaches is based on using ontology knowledge model integrating knowledge about decision-making process [9]. It includes such elements as the decision-making situation, the decision problem, a set of alternatives and evaluation criteria, rules, preferences and decision-makers. Then the developed model was verified within the problem of decision-making for the ERP system selection. The proposed approach was later extended by ontology components based on a generalized approach to formalization of methods of decision support [10]. The proposed ontologies focused on knowledge that makes it possible to structure knowledge about the decision problem. However, they take the problem of systematization of knowledge about the various methods of multi-criteria 
decision support only to a small extent. Characterized ontologies do not include knowledge about the characteristics of the different MCDA methods and their environmental context and use cases [7].

The purpose of this article is to develop a ontology based knowledge model of MCDA methods. Taking into account the contemporary standards of knowledge engineering, it is justified to implement a repository of knowledge in the form of ontologies. In order to build the first stage of such a solution, literature related to MCDA methods was reviewed and analyzed. This formed the basis of the development of a taxonomy and ontology. Ontology as a proposed form of the conceptualization can be used as a source of knowledge that can be used repeatedly. The study was divided into two parts: a discussion of the literature and the development of a taxonomy of MCDA methods together with the ontology of MCDA methods. The article ends with the author's practical ontology verification using competency questions.

\section{METHODS OF MULTI-CRITERIA DECISION SUPPORT}

Research on MCDA area led to the development of two main groups of methods and directions. They differ significantly from each other both in the approach to the decision situation and in the way of choosing the best alternative . These are approaches based on utility theory and outranking relations [4]. An approach based on utility theory is derived from the American MCDA school. Two kinds of relationships between alternatives are identified:

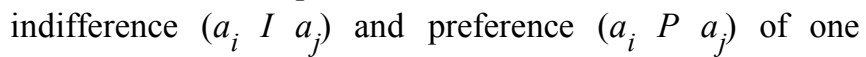
alternative over another. The methods in this group exclude non-comparability of the decision variants and assume transitivity of preference [4]. Among the methods based on utility theory main approaches include: MAUT (MultiAttribute Utility Theory), AHP (Analytic Hierarchy Process), and UTA (Additive Utility Theory). These methods usually do not take into account the uncertainty, vagueness and ambiguity that can occur in the data [4]. Methods based on outranking relations are derived from the European MCDA school and the outranking relationship is characterized by the lack of transitivity between pairs of decision variants.. These methods mainly include methods from ELECTRE family (ELimination Et Choin Traduisant la REalite) and PROMETHEE (Preference Ranking Organization Method for Enrichment Evaluations). Methods from this group frequently extend a set of basic preferential situations with the result that includes indifference of decision variants $\left(a_{i} I a_{j}\right)$, weak preference one variant over another $\left(a_{i} Q a_{j}\right)$, the strict preference of a variant of the decision-making relative to the other $\left(a_{i} P a_{j}\right)$, and incomparability between data variations $\left(a_{i} R a_{j}\right)$ [18]. Furthermore, couples of variants can be grouped to determine the relationship connecting the two or three basic situations. With the occurrence of the grouped relationship, it is impossible to distinguish, without additional parameters, the basic relationship of the grouped situations. Such situations are: "nonpreference" which are groups of indifference and incomparability situations $\left(a_{i} \quad \begin{array}{lll}N & a_{j}\end{array}\right)$, "preference" which are situations of weak and strict preference $\left(a_{i} L a_{j}\right)$, "guess preference" which combines situations of indifference and weak preference $\left(a_{i} J a_{j}\right)$, " $\mathrm{K}$ preference" which are groups of strict preferences and situations of incomparability $\left(a_{i} K a_{j}\right)$, and "outranking" which contains the situations of indifference strong and weak preference $\left(a_{i} S a_{j}\right)$ [12]. Due to variations of the relationship between the decision-making, two basic approaches can be distinguished to aggregate operational performance variants : (1) aggregate to a single criterion (2) aggregation by using the outranking relationship [12]. The first operational approach excludes the incomparability situation and contains only the most indifference relationships and strict preference. It is strongly associated with the American school of decision support. The second approach takes into account incomparability and outranking and is generally used in the methods derived from the European MCDA school. Based on an analysis of the literature, a complex set of available MCDA methods was identified and the general characteristics of which are shown in Table 1. The exact classification of methods along with the characteristics is presented in the rest of the article followed by a description of the process of building a taxonomy of MCDA methods.

\section{BUILDING TAXONOMY AND ONTOLOGY OF MULTI-CRITERIA DECISION SUPPORT}

Ontology is treated in the literature as a set of definitions of the terms of the area and the relationship between them [3]. It is also referred to as the specification conceptualization providing a description of the concepts and relationships that occur between them [2]. The use of ontologies as a solution supporting the choice of an MCDA method is designed to assist the user in selecting the right solution for a given decision situation described using specific criteria and parameters. The ontology should also provide detailed information about the various methods for multi-criteria decision support.

The first step in the construction of an ontology is to develop a taxonomy of criteria describing the MCDA methods. Identification and analysis were based on the analysis of 25 MCDA methods for creation of a set of criteria and sub-criteria characterizing the different solutions. A total set was formed comprising four main criteria (available binary relations, linear compensation effect, the type of aggregation and the type of preferential information) and 16 sub-criteria. This collection was also 
TABLE I. CHARACTERISTICS OF SELECTED METHODS OF MCDA

\begin{tabular}{|c|c|c|}
\hline Method name & Essence of the method & Reference \\
\hline AHP & $\begin{array}{l}\text { The problem is formulated in a hierarchical form. Overall rank is based on the collective aggregation } \\
\text { of partial marks obtained in a paired comparisons in matrix. }\end{array}$ & [19] \\
\hline Additive weight method & $\begin{array}{l}\text { Aggregation based on the inadditive function. Choosing the best alternative with the highest value of } \\
\text { the global index obtained as the sum of the partial marks for all criteria. }\end{array}$ & {$[20]$} \\
\hline EVAMIX & $\begin{array}{l}\text { Ranking of alternatives on the basis of global dominance index (ordinal indices and cardinal } \\
\text { dominance). }\end{array}$ & {$[21]$} \\
\hline Electre I & $\begin{array}{l}\text { The aim of the method is to determine the subset of variants containing the best alternative. The } \\
\text { procedure is based on the construction of compliance and non-compliance tests, following the } \\
\text { structure of the outranking graph. Preferences modeling is done using the true criteria. }\end{array}$ & {$[22]$} \\
\hline Electre II & $\begin{array}{l}\text { Extension of ELECTRE I method. The essential part is the use of two outranking relations :weak and } \\
\text { strong. }\end{array}$ & {$[23]$} \\
\hline Electre III & $\begin{array}{l}\text { Ranking of variants based on outranking relationship. Modeling preferences with pseudo criteria and } \\
\text { weights. }\end{array}$ & {$[24]$} \\
\hline Electre IS & $\begin{array}{l}\text { The method constitutes a development of ELECTRE I with additional modeling preferences based on } \\
\text { pseudo criteria. }\end{array}$ & {$[25]$} \\
\hline Electre IV & $\begin{array}{l}\text { Ranking of variants based on the relationship with outranking pseudo criteria. It does not apply } \\
\text { weights to the criteria. }\end{array}$ & {$[26]$} \\
\hline Electre TRI & $\begin{array}{l}\text { Sorting variants into categories based on outranking relationship. Modeling preferences with pseudo } \\
\text { criteria. }\end{array}$ & {$[1]$} \\
\hline MAUT & Ranking of variants based on the aggregation of sub-additive utility function form. & {$[27]$} \\
\hline MAVT & Ranking of variants based on the aggregation of multiplicative utility function. & {$[27]$} \\
\hline MELCHIOR & The extension of the ELECTRE IV method. Ordinal relationship validity of the criteria is added. & {$[28]$} \\
\hline Maximin method & The aim of the method is to choose the strongest variant of the weakest. & {$[20]$} \\
\hline Maximin fuzzy method & $\begin{array}{l}\text { The aim of the method is to choose the strongest variant of the weakest. Evaluation of alternatives has } \\
\text { the fuzzy form. }\end{array}$ & {$[29]$} \\
\hline $\begin{array}{l}\text { Methods of extracting the } \\
\text { minimum and maximum } \\
\text { values of the attribute }\end{array}$ & Methods reject criterion values successively above and below the predetermined value. & {$[20]$} \\
\hline NAIADE & $\begin{array}{l}\text { Application of fuzzy measures distances and of paired comparison. Calculation of preferences as in } \\
\text { PROMETHEE. }\end{array}$ & {$[30]$} \\
\hline ORESTE & Uses alternatives assessment and weighting of the criteria described only on an ordinal scale. & {$[31]$} \\
\hline PROMETHEE I & $\begin{array}{l}\text { The method constitutes a development of ELECTRE methods, but expanded the number of binary } \\
\text { relations describing preferences to six. }\end{array}$ & {$[32]$} \\
\hline PROMETHEE II & Extension of PROMETHEE I by the global results for all variants. & {$[32]$} \\
\hline REGIME & $\begin{array}{l}\text { The method is based on a pairwise comparisons matrix. Scale }\{1,0,1\} \text { is used. The values of the } \\
\text { scale correspond to the domination, equivalence and dominance. }\end{array}$ & {$[33]$} \\
\hline Additive fuzzy weight method & $\begin{array}{l}\text { The method is based on a fuzzy version of the additive weight method where weight and evaluation } \\
\text { are modeled as fuzzy numbers. }\end{array}$ & {$[34]$} \\
\hline $\begin{array}{l}\text { Fuzzy methods of extracting } \\
\text { the minimum and maximum } \\
\text { values of the attribute }\end{array}$ & $\begin{array}{l}\text { Methods reject variants' criterion values successively above and below the predetermined value. Take } \\
\text { the form of fuzzy evaluation. }\end{array}$ & {$[35]$} \\
\hline SMART & $\begin{array}{l}\text { Ranking of variants based on the aggregation of partial form of additive utility function. Global } \\
\text { evaluations are calculated as a weighted average of partial evaluations. }\end{array}$ & {$[36]$} \\
\hline TOPSIS & $\begin{array}{l}\text { Choice of the best option is based on the multidimensional evaluation of the distance from the ideal } \\
\text { and opposite solutions. }\end{array}$ & {$[20]$} \\
\hline UTA & $\begin{array}{l}\text { The model is additive utility function. Partial utilities are determined by using principles of ordinal } \\
\text { regression. }\end{array}$ & [37] \\
\hline
\end{tabular}

the basis for the construction of taxonomies of analyzed solutions. Table 2 presents a summary of the criteria and information about them by the various methods of multicriteria decision support.

Based on a defined set of criteria, sub-criteria, and information about fulfilling them by selected solutions, the taxonomy created solutions for specific MCDA methods. This taxonomy is presented in the ontological form. This task requires distinguishing the concept on the basis of criteria and sub-criteria and establishing their hierarchy.
Figure 1 presents a graphical diagram of a set of criteria and sub-criteria of the main built taxonomy. The taxonomy provides a set of MCDA methods shown in Table 2, with a set of differentiating criteria and a network of taxonomic relationships between concepts (relations between the different classes of instances). Using this taxonomy, there is a possibility to select methods based on selected criteria.

A detailed analysis of taxonomic relationships reveals the full features of the different MCDA methods. This is the basis for a simple reusable but structured domain 
TABLE II. TAXONOMY OF SELECTED METHODS OF MCDA

\begin{tabular}{|c|c|c|c|c|c|c|c|c|c|c|c|c|c|c|c|c|}
\hline \multirow{2}{*}{$\begin{array}{c}\text { Criterion } \\
\text { Method name }\end{array}$} & \multicolumn{5}{|c|}{$\begin{array}{c}\text { Available binary } \\
\text { relations }\end{array}$} & \multicolumn{3}{|c|}{$\begin{array}{c}\text { Linear compensation } \\
\text { effect }\end{array}$} & \multicolumn{3}{|c|}{ Type of aggregation } & \multicolumn{5}{|c|}{ Type of preferential information } \\
\hline & I & $\mathbf{P}$ & $\mathbf{Q}$ & $\mathbf{R}$ & $\mathbf{s}$ & No & Total & Partial & $\begin{array}{l}\text { Single } \\
\text { criterion }\end{array}$ & $\begin{array}{c}\text { Outran } \\
\text { king }\end{array}$ & $\underset{\text { d }}{\text { Mixe }}$ & $\begin{array}{c}\text { Determin } \\
\text { istic }\end{array}$ & $\begin{array}{c}\text { Cardi } \\
\text { nal }\end{array}$ & $\begin{array}{c}\text { Non- } \\
\text { determinis } \\
\text { tic }\end{array}$ & $\begin{array}{c}\text { Ordin } \\
\text { al }\end{array}$ & Fuzzy \\
\hline AHP & $\mathrm{Y}$ & $\mathrm{Y}$ & & & & & & $\mathrm{Y}$ & $\mathrm{Y}$ & & & Y & $\mathrm{Y}$ & $\mathrm{Y}$ & & \\
\hline Additive weight method & $\mathrm{Y}$ & $\mathrm{Y}$ & & & & & $\mathrm{Y}$ & & $\mathrm{Y}$ & & & $\mathrm{Y}$ & $\mathrm{Y}$ & & & \\
\hline EVAMIX & $\mathrm{Y}$ & $\mathrm{Y}$ & & & & & & $\mathrm{Y}$ & $\mathrm{Y}$ & & & $\mathrm{Y}$ & $\mathrm{Y}$ & & $\mathrm{Y}$ & \\
\hline Electre I & & & & $\mathrm{Y}$ & $\mathrm{Y}$ & & & $\mathrm{Y}$ & & $\mathrm{Y}$ & & $\mathrm{Y}$ & $\mathrm{Y}$ & & $\mathrm{Y}$ & \\
\hline Electre II & & & & $\mathrm{Y}$ & $\mathrm{Y}$ & & & $\mathrm{Y}$ & & $\mathrm{Y}$ & & $\mathrm{Y}$ & $\mathrm{Y}$ & & $\mathrm{Y}$ & \\
\hline Electre III & & & & $\mathrm{Y}$ & $\mathrm{Y}$ & & & $\mathrm{Y}$ & & $\mathrm{Y}$ & & $\mathrm{Y}$ & $\mathrm{Y}$ & & $\mathrm{Y}$ & \\
\hline Electre IS & & & & $\mathrm{Y}$ & $\mathrm{Y}$ & & & $\mathrm{Y}$ & & $\mathrm{Y}$ & & $\mathrm{Y}$ & $\mathrm{Y}$ & & $\mathrm{Y}$ & \\
\hline Electre IV & & & & $\mathrm{Y}$ & $\mathrm{Y}$ & & & $\mathrm{Y}$ & & $\mathrm{Y}$ & & $\mathrm{Y}$ & $\mathrm{Y}$ & & $\mathrm{Y}$ & \\
\hline Electre TRI & & & & $\mathrm{Y}$ & $\mathrm{Y}$ & & & $\mathrm{Y}$ & & $\mathrm{Y}$ & & $\mathrm{Y}$ & $\mathrm{Y}$ & & $\mathrm{Y}$ & \\
\hline MAUT & $\mathrm{Y}$ & $\mathrm{Y}$ & & & & & & $\mathrm{Y}$ & $\mathrm{Y}$ & & & & $\mathrm{Y}$ & $\mathrm{Y}$ & & \\
\hline MAVT & $\mathrm{Y}$ & $\mathrm{Y}$ & & & & & & $\mathrm{Y}$ & $\mathrm{Y}$ & & & $\mathrm{Y}$ & $\mathrm{Y}$ & & & \\
\hline MELCHIOR & & & & $\mathrm{Y}$ & $\mathrm{Y}$ & & & $\mathrm{Y}$ & & $\mathrm{Y}$ & & $\mathrm{Y}$ & & & $\mathrm{Y}$ & \\
\hline Maximin & $\mathrm{Y}$ & Y & & & & $\mathrm{Y}$ & & & $\mathrm{Y}$ & & & $\mathrm{Y}$ & $\mathrm{Y}$ & & $\mathrm{Y}$ & \\
\hline Maximin fuzzy method & $\mathrm{Y}$ & $\mathrm{Y}$ & $\mathrm{Y}$ & & & $\mathrm{Y}$ & & & $\mathrm{Y}$ & & & $\mathrm{Y}$ & $\mathrm{Y}$ & $\mathrm{Y}$ & $\mathrm{Y}$ & $\mathrm{Y}$ \\
\hline $\begin{array}{l}\text { Methods of extracting the } \\
\text { minimum and maximum values } \\
\text { of the attribute }\end{array}$ & $Y$ & Y & & & & Y & & & & & $\mathrm{Y}$ & Y & $\mathrm{Y}$ & & $\mathrm{Y}$ & \\
\hline NAIADE & . & & & $\mathrm{Y}$ & $\mathrm{Y}$ & & & $\mathrm{Y}$ & & $\mathrm{Y}$ & & $\mathrm{Y}$ & $\mathrm{Y}$ & $\mathrm{Y}$ & $\mathrm{Y}$ & $\mathrm{Y}$ \\
\hline ORESTE & $\mathrm{Y}$ & $\mathrm{Y}$ & & $\mathrm{Y}$ & & & & $\mathrm{Y}$ & & $\mathrm{Y}$ & & $\mathrm{Y}$ & & & $\mathrm{Y}$ & \\
\hline PROMETHEE I & $\mathrm{Y}$ & $\mathrm{Y}$ & & $\mathrm{Y}$ & & & & $\mathrm{Y}$ & & $\mathrm{Y}$ & & $\mathrm{Y}$ & $\mathrm{Y}$ & & $\mathrm{Y}$ & \\
\hline PROMETHEE II & $\mathrm{Y}$ & $\mathrm{Y}$ & & & & & & $\mathrm{Y}$ & & $\mathrm{Y}$ & & $\mathrm{Y}$ & $\mathrm{Y}$ & & $\mathrm{Y}$ & \\
\hline REGIME & & & & $\mathrm{Y}$ & $\mathrm{Y}$ & & & $\mathrm{Y}$ & & $\mathrm{Y}$ & & $\mathrm{Y}$ & & & $\mathrm{Y}$ & \\
\hline Additive fuzzy weight method & $\mathrm{Y}$ & $\mathrm{Y}$ & $\mathrm{Y}$ & & & & $\mathrm{Y}$ & & $\mathrm{Y}$ & & & & $\mathrm{Y}$ & $\mathrm{Y}$ & $\mathrm{Y}$ & $\mathrm{Y}$ \\
\hline $\begin{array}{l}\text { Fuzzy methods of extracting the } \\
\text { minimum and maximum values } \\
\text { of the attribute }\end{array}$ & $\mathrm{Y}$ & Y & $\mathrm{Y}$ & & & Y & & & & & $\mathrm{Y}$ & & Y & $\mathrm{Y}$ & Y & Y \\
\hline SMART & Y & $\mathrm{Y}$ & & & & & & $\mathrm{Y}$ & $\mathrm{Y}$ & & & $\mathrm{Y}$ & $\mathrm{Y}$ & & & \\
\hline TOPSIS & Y & $\mathrm{Y}$ & & & & & $\mathrm{Y}$ & & $\mathrm{Y}$ & & & $\mathrm{Y}$ & $\mathrm{Y}$ & & & \\
\hline UTA & $\mathrm{Y}$ & $\mathrm{Y}$ & & & & & & $\mathrm{Y}$ & $\mathrm{Y}$ & & & Y & & & $\mathrm{Y}$ & \\
\hline
\end{tabular}

knowledge area. Based on preset criteria a user can receive detailed information about the satisfying method (methods) with its specific taxonomic characteristics. An example set of graphical results is shown in Figure 2, illustrating a method (here ELECTRE Tri) which met the criteria for the query: binary relations $\mathrm{R}$ and $\mathrm{S}$, the partial effect of linear

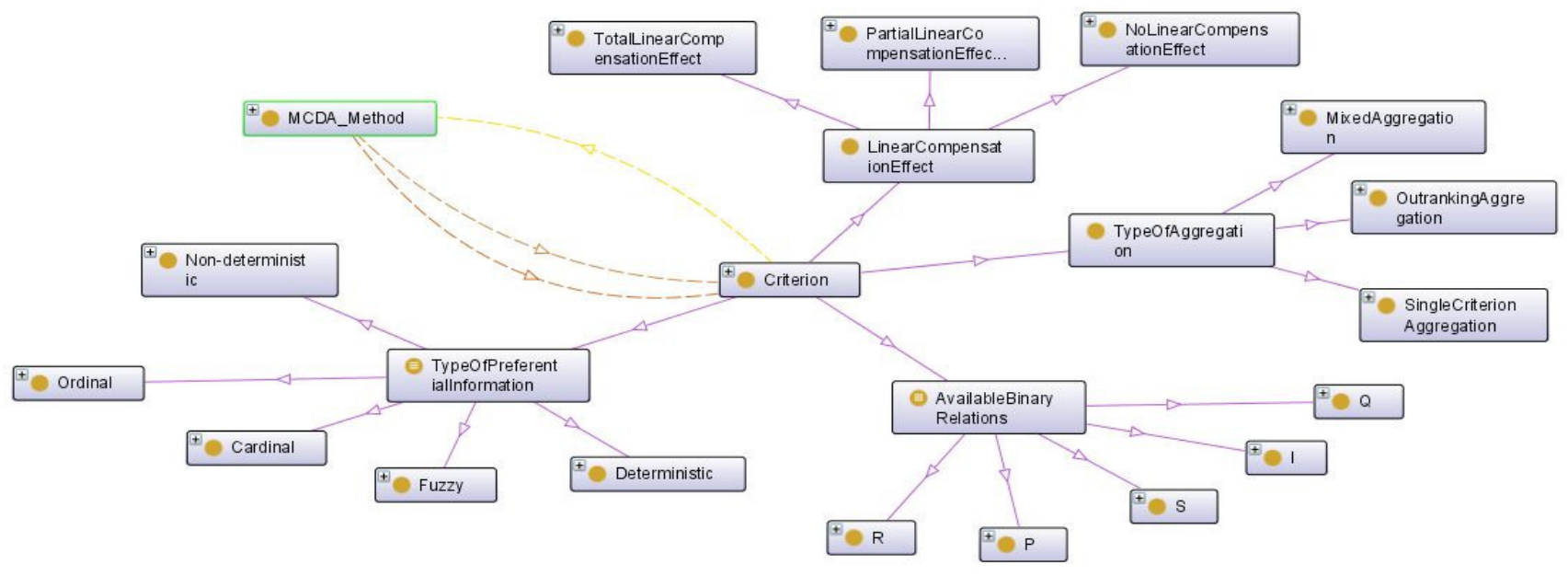

Fig 1. Elements of MCDA method taxonomy - set of criteria 




Fig 2. Graphical representation of competence query

compensation, aggregation using outranking relations, the type of preferential information - order.

\section{CONCLUSION}

This article discusses the problem of the construction of a taxonomy of MCDA methods and reference examples. The paper presents characteristics of identified MCDA methods. Based on the following analysis an identified set of criteria and sub-criteria characterizing the different solutions was presented. The results formed the basis for the construction of taxonomic relationships between the different MCDA methods and a complete taxonomy of MCDA methods and their use cases.

The results confirmed the possibility of the conceptualization of knowledge in the area of MCDA methods. The use of the proposed taxonomy supports the decision-maker's correct choice of multi-criteria method and allows for full domain knowledge about each one. It should be noted that the standard used for the construction of the ontology (OWL) ensures full compliance with current international semantic standards. This allows further use of the developed solution as well as its connection to other ontologies in various fields within the rapidly growing trend of knowledge engineering.

Further research should be supplemented by ontology of reference cases of the application of each method in various areas (management, logistics, environment, medicine, etc.) and reference publications characterizing the different MCDA methods. For ontology, additional multi-criteria methods can be attached, as well as criteria characterizing the various methods and the environmental context of their use. It makes possible the greater use of the adequacy of the reasoner and requests the use of various methods in decision problems using SWRL language rules.

\section{ACKNOWLEDGMENT}

The work was partially supported by Fellowship coFinanced by European Union within European Social Fund, by European Union's Seventh Framework Programme for research, technological development and demonstration under grant agreement no 316097 [ENGINE].

\section{REFERENCES}

[1] D. Bouyssou, B. Roy, Aide Multicritere a la decision: Methodes et Cas. Paris: Economica, 1993.

[2] W. Gliński, "Kwestie metodyczne projektowania ontologii w systemach informacyjnych," in Strategie informatyzacji i zarządzanie wiedzą, Z. Szyjewski, Ed. Warszawa:WNT, 2004, pp. 201-212.

[3] T.R. Gruber, "A translation approach to portable ontology specifications," Knowledge Acquisition, vol. 5, no. 2, pp. 199-220, 1993.

[4] T. Trzaskalik, Metody wielokryterialne na polskim rynku finansowym. Warszawa: Polskie Wydawnictwo Ekonomiczne, 2006.

[5] http://protege.stanford.edu/

[6] J. Chai J., J.N.K. Liu, “An Ontology-driven Framework for Supporting Complex Decision Process," World Automation Congress (WAC), 2010.

[7] J. Wątróbski, J. Jankowski, Z. Piotrowski, "The Selection of Multicriteria Method Based on Unstructured Decision Problem Description," Lecture Notes in Artificial Intelligence, vol. 8733, pp. 454-465, 2014, http://dx.doi.org/10.1007/978-3-319-11289-3_46

[8] X.Y. Liao, E. Rocha Loures, O. Canciglieri, H. Panetto, "A Novel Approach for Ontological Representation of Analytic Hierarchy Process," Advanced Materials Research, vol. 988, pp. 675-68, 2014, http://dx.doi.org/10.4028/www.scientific.net/AMR.988.675 
[9] E. Kornyshova, R. Deneckere, "Using an Ontology for Modeling Decision-Making Knowledge," Frontiers in Artificial Intelligence and Applications, vol. 243, pp. 1553-1562, 2012.

[10] E. Kornyshova, R. Deneckere, "Decision-Making Ontology for Information System Engineering," Lecture Notes in Computer Science, vol. 6412, pp. 104-117, 2010

[11] P. Ziemba, M. Piwowarski, J. Jankowski, J. Wątróbski, "Method of Criteria Selection and Weights Calculation in the Process of Web Projects Evaluation," Lecture Notes in Artificial Intelligence, vol. 8733, pp. 684-693, 2014, http://dx.doi.org/10.1007/978-3-319-11289-3 69

[12] B. Roy, Multicriteria Methodology for Decision Aiding. Dord̄recht: Springer, 1996.

[13] M. Velasquez, P.T. Hester, "An Analysis of Multi-Criteria Decision Making Methods," International Journal of Operations Research, vol. 10 , no. 2, pp. 56-66, 2013.

[14] B.C. Grau, I. Horrocks, B. Motik, B. Parsia, P. Patel-Schneider, U. Sattler, "OWL 2: The Next Step for OWL," Web Semantics: Science, Services and Agents on the World Wide Web, vol. 6, no. 4, pp. 309-322, 2008.

[15] O. Corcho, M. Fernandez-Lopez, A. Gomez-Perez, A. Lopez-Cima, "Building Legal Ontologies with METHONTOLOGY and WebODE,' Lecture Notes in Computer Science, vol. 3369, pp. 142-157, 2005.

[16] F. Baader, I. Horrocks, U. Sattler, "Description Logics," in Handbook On Ontologies. Second Edition, S. Staab, R. Studer, Ed. Berlin: Springer, 2009, pp. 21-43.

[17] E. Della Valle, S. Ceri, "Querying the Semantic Web: SPARQL," in Handbook of Semantic Web Technologies, J. Domingue, D. Fensel, J.A Hendler, Ed. Berlin: Springer, 2011, pp. 299-363.

[18] B. Roy, "The Outranking Approach and the Foundations of Electre Methods," Theory and Decision, vol. 31, no. 1, pp 49-73, 1991.

[19] T. Saaty, The Analytic Hierarchy Process. New York: McGraw-Hill, 1980.

[20] C.L. Hwang, K. Yoon, Multiple Attribute Decision Making: Methods and Applications. Berlin: Springer, 1981.

[21] H. Voogd, "Multicriteria evaluation with mixed qualitative and quantitative data," Environment and Planning B, vol. 9, pp. 221-236, 1982.

[22] B. Roy, "Classement et choix en presence de points de vue multiples (la methode Electre)," Revue Francaise d'Informatique et de Recherche Operationnelle, vol. 8, pp. 57-75, 1968.
[23] B. Roy, P. Bertier, "La methode Electre II - une application au media planning," in Operational Research OR'72, 1973, pp. 291-302.

[24] B. Roy, "Electre III: un algorithme de classement fonde sur une representation floue des preferences en presence de criteres multiples," Cahiers du CERO, vol. 20, pp. 3-24, 1978.

[25] B. Roy, J.M. Skalka, "Electre IS - aspects methodologiques et guide d'utilisation," Document du LAMSADE 30, 1984, 125 p.

[26] B. Roy, J.C. Hugonnard, "Ranking of suburban line extension projects on the Paris metro system by a multicriteria method," Transportation Research, vol. 16A, pp. 301-312, 1982.

[27] R.L. Keeney, H. Raiffa, Decisions with Multiple Objectives: Preferences and Value Tradeoffs. New York: Wiley, 1976.

[28] J.P. Leclercq, "Propositions d'extensions de la notion de dominance en presence de relations d 'ordre sur les pseudo-criteres: Melchior. Revue BeIge de Recherche Operationnelle," de Statistique et d'Informatique, vol. 24, pp. 32-46, 1984

[29] R.E. Bellman, L.A. Zadeh, "Decision-Making in a Fuzzy Environment," Management Science, vol. 17B, no. 4, pp. 141-164, 1970.

[30] G. Munda, Multicriteria Evaluation in a Fuzzy Environment, Heidelberg: Physica-Verlag, 1995.

[31] M. Roubens, "Preference relations on actions and criteria in multicriteria decision making," European Journal of Operational Research, vol. 10, pp.51-55, 1982 .

[32] J.P. Brans, B. Mareschal, P. Vincke, "Promethee: A new family of outranking methods in multicriteria analysis," in Operational Research OR'84, 1984, pp. 408-421.

[33] E. Hinlopen, P. Nijkamp, P. Rietveld, "Qualitative discrete multiple criteria choice models in regional planning," Regional Science and Urban Economics, vol. 13, pp.77-102, 1983.

[34] D. Dubois, H. Prade, "The use of fuzzy numbers in decision analysis," in Fuzzy Information and Decision Process, M.M. Gupta, E. Sanchez, Ed. Amsterdam, 1982, pp. 309-321.

[35] D. Dubois, H. Prade, C. Testemale, "Weighted fuzzy pattern matching," Fuzzy Sets and Systems, vol. 28, no. 3, pp. 313-331, 1988

[36] W. Edwards, J.R. Newman, Multiattribute Evaluation. Beverly Hills, CA:Sage, 1982

[37] E. Jacquet-Lagrèze, J. Siskos, "Assessing a set of additive utility functions for multi-criteria decision making: The UTA method," European Journal of Operational Research, vol. 10, pp. 151-164, 1982. 